\title{
The concept of vicarious suffering in the Old Testament
}

\begin{abstract}
Authors:
Ananda B. Geyser-Fouchè ${ }^{1}$

Thomas M. Munengwa ${ }^{1,2}$ (1)

\section{Affiliations:}

${ }^{1}$ Department Old Testament Studies, Faculty of Theology, University of Pretoria, Pretoria, South Africa

${ }^{2}$ College of Social Sciences, Theology, Humanities and Education, Institute of Theology and Religious Studies, Africa University, Mutare, Zimbabwe

Research Project Registration: Project Leader:

A.B. Geyser-Fouchè

Project Number: 1258230

Description:

This research is part of the project, 'Second Temple Literature and Qumran', directed by Dr Ananda Geyser-Fouche of the Department Old Testament Studies, Faculty of Theology, University of Pretoria.
\end{abstract}

Corresponding author: Ananda Geyser-Fouchè, ananda.geyser-fouche@ up.ac.za

\section{Dates:}

Received: 06 Dec. 2018 Accepted: 31 May 2019 Published: 13 Aug. 2019

How to cite this article: Geyser-Fouchè, A.B. \& Munengwa, T.M., 2019, 'The concept of vicarious suffering in the Old Testament', HTS Teologiese Studies/ Theological Studies 75(4), a5352. https://doi.org/ 10.4102/hts.v75i4.5352

\section{Copyright:}

(c) 2019. The Authors. Licensee: AOSIS. This work is licensed under the Creative Commons Attribution License.

\section{Read online:}

Scan this QR
code with your
smart phone or
mobile device
to read online.

The concept of vicarious suffering has been used to describe some form(s) of suffering in the Old Testament. The use of this concept has, however, been a source of much debate and controversy. In this article, the meaning of the concept of vicarious suffering, its presence in the Old Testament, as well as its 'appropriateness' and usefulness as a heuristic term in the study of the Old Testament account of suffering is discussed. Vicarious suffering is defined as 'suffering in place of and for the benefit of others'. The study establishes that while a number of terms and practices in the Old Testament express the idea of vicariousness, the concept of vicarious suffering finds its fullest and dramatic expression in Isaiah 52:13-53:12. Therefore, the article concludes by proposing that the concept of vicarious suffering is present in the Old Testament, particularly in Isaiah 52:13-53:12, and that it continues to be an appropriate and useful heuristic concept in the study of the issue of suffering in the Old Testament.

Keywords: Suffering; Vicarious suffering; Divine suffering; Just retribution; Isaiah 52:13-53.

\section{Introduction}

Suffering is a phenomenon of human experience. It is part of human life (Magnante 1997:9). It is unavoidable and one can even venture to say necessary. ${ }^{1}$ In every society, epoch, religion and human discipline, there have been and continue to be repeated efforts at describing and making sense of human suffering. As well as accepting suffering as part and parcel of the human condition, there have been incessant efforts at responding to the natural human question, why? Why do humans suffer? What is the purpose, if any, of suffering? ${ }^{2}$ In theological circles, suffering has also been extended to God, in the concept of 'divine suffering'. In this understanding, God is said to suffer in solidarity with human beings. ${ }^{3}$

It is not an exaggeration to say that one of the themes of the Old Testament is that of making sense of human suffering, in general (cf. Gn 2-3; Villiers 2009:4-17), the suffering of Israel (Isa 50:1; Ps 44) and the suffering of the innocent, in particular (Jr 12:1-5; Job). In these religious texts, the issue of suffering is approached from the perspective of Israel's faith in God, the creator of the universe and the creator of the nation of Israel, and from the perspective of the 'relationships' among the Israelites and other nations, on the one hand, and their relationship with God, on the other. The concept of vicarious suffering is one way of speaking of and making sense of the suffering of the innocent in the Old Testament as this article endeavours to demonstrate. However, before doing so, it is also important to briefly look at the issue of suffering in general.

\section{Suffering in general}

The issue of suffering has been at the heart of the human quest for meaning. This theme has been treated in various ways and for various reasons. For the purpose of establishing a common ground of departure, the etymology of the word 'suffering', the contemporary account concerning the

1.Suffering has been traditionally seen not only as part and parcel of human experience, but also as a unique human capacity. While the former is generally accepted, the latter has recently been challenged in the light of scientific evidence suggesting the contrary. For further discussions on this issue, together with the issue of redemption as uniquely human, see Sollereder 2015:17-22.

2.Liderbach (1992) addresses this question and provides endeavours by past philosophers and religious thinkers in proposing possible answers to this question and concludes by creating what he calls 'a myth' in an effort to help people to face suffering with some form of understanding and purposeful optimism.

3.For more on the concept of divine suffering, its origins, meaning and appropriateness, see Herdt (2001).

Note: HTS 75th Anniversary Maake Masango Dedication.

This article represents a reworked version of aspects from the PhD-thesis of Thomas Munengwa, titled, 'Vicarious suffering in Old Testament wisdom literature and the wisdom tradition: A traditio-historical approach', completed under the supervision of Dr Geyser-Fouchè, Department of Old Testament Studies, Faculty of Theology and Religion, University of Pretoria. 
cause(s) and meaning of suffering and suffering in the Old Testament will be examined. A working definition of suffering will also be proposed.

\section{Etymological considerations}

The English word 'suffering' is often traced back to Middle English. ${ }^{4}$ It is said to have originated from the Latin suffero, sufferre, sustuli/sublatus - sub [from below] and ferre [to bear], through Anglo-Norman French suffrir - to suffer (Pearsall \& Trumble 2002). The basic etymological nuance is that of carrying a burden. A burden is something that causes either physical or emotional discomfort or both. It is something that one suffers.

The word 'suffering' may be construed as either an abstract noun, like in the expression, 'the suffering of God', or a qualifying term, as in the expression, 'the suffering servant'. Suffering is also used as a qualifying term for the mental state of a person or group of persons, as in the expressions: 'the suffering people of God' or 'the suffering servant'.

\section{'Standard account of suffering'}

Contemporary discussions on the issue of suffering may be summarised under three headings: efforts at describing what suffering is, efforts at categorising different types of suffering and efforts at outlining and describing different 'cures' for suffering. These discussions continue to take place from the perspectives of different disciplines. ${ }^{5}$

The concept of suffering has proved to be elusive to a concise and common definition. Each discipline seems to define it from its own perspective (cf. Becking 2009:183-185). It has been defined as: 'a negative basic feeling or emotion that involves a subjective character of unpleasantness, aversion, harm or threat of harm to body or mind' (Hudson 2012:171) or as: '... the state of severe distress associated with the events that threaten the intactness of a person' (Cassell 1991:33). Common to these definitions is the fact that suffering is understood in terms of emotional anguish, that suffering is personal ${ }^{6}$ and that suffering involves perceived harm and/or threat. In the light of these submissions, the following definition is proposed for this study: Suffering is a personal emotional anguish arising from various sources perceived to be harmful and life threatening.

Sources or causes of this emotional anguish are seen as many and various. While pain is considered to be one of the main sources (cf. Chapman \& Gavrin 1999), it is generally said that this emotional agony is, ultimately, a result of the failure to

4.The dating of this period is debated. One view dates the period between 1100 and 1500 , after the Norman invasion and before the arrival of the printing press in Britain (1476).

5.There is numerous literature on this topic, including the following: Magnante (1997), Laato and De Moor (2003), Morgan and Peterson (2008) and Becking and Human (2009) (Biblical pors (2003), Morgan and Peterson (2008) and Becking and Human (2009) (Biblical perspective); Bowker (1900) (World Religions perspective); Cassell (2012) (Philosophical perspective); and Akhtar (2014) (Psychological perspective).

6.This does not preclude the fact that there are experiences that are generally accepted as causing human suffering, such as death and torture (Cassell 1991:44). understand, as well as refusal to accept what one is going through (cf. Cassell 1991:32-33). Events and experiences are not seen as fitting into the perceived scheme of things or desires of the sufferer. Hence, suffering is an issue of the mind.

Numerous ways for coping with suffering have been proposed from various perspectives and traditions. These include attempts at providing a rational explanation to the problem as in the various strands of theodicy; accepting what one is going through; controlling and, where necessary, annihilating desire as in the case of Buddhism; distinguishing between a suffering that is part and parcel of human existence; and a suffering that is pathological and remediable (cf. Akhtar 2014:xiii).

\section{Suffering in the Old Testament}

The Old Testament does not provide a systematic treatment of the issue of suffering. However, beginning with Genesis 3, we find the issue of suffering scattered throughout the Old Testament. One comes across verses, chapters and even entire books concerned with issues of suffering, either suffering in general or the suffering of the innocent, and even both. In all these, one witnesses, on the one hand, a variety of interpretations and understanding of the nature, origin or source and cause(s) of suffering, ${ }^{7}$ and on the other hand, complaints or lamentations or the carpe diem ${ }^{8}$ attitude, as part of the process of grappling with and 'explaining' the issue of suffering. ${ }^{9}$

Numerous terms and expressions are used to describe this

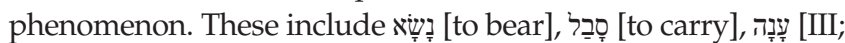
to be afflicted] and its cognates (cf. Ps 107:17, 116:10, 119:67, Is 53:4); עִצֶב [pain, toil] and its cognates (cf. Gn 3:16, 17); צָָָּ' [pain, toil] and its cognates (cf. Qoh 1:3, 2:18, 5:17, Job 3:10, 4:8); ירגה [to suffer] and its cognates (cf. Job 19:2, Lm 1:12); כְאב (pain, sorrow) and its cognates (cf. Ex 3:7, Job 2:13, Qoh 1:18, Ps 32:10, Is 53:3,4); כַעַ (sorrow, vexation) and its cognates; רִ רע ([misfortune], suffering, cf. Job 2:10), to mention a few. Basically, the words and expressions can be divided into two groups; those that express the idea of carrying, bearing, like

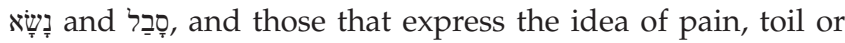
sorrow. The latter seems to be in the majority.

Suffering in the Old Testament then is mostly understood in terms of pain, sorrow, affliction and anguish. This anguish or pain emanates from different and numerous experiences, such as sickness, loss (of loved ones, property, land), guilt and frustration with the absence of God (cf. Simundson 1992:219). The pain or affliction may also be physical pain and/or emotional pain. The physical pain includes pain brought

7.Genesis $2-3$ is a good example of a text on the aetiology of suffering (cf. Simundson 1992: 220) and the solidarity aspect of suffering (Humbert 1918:117).

8.This is a Latin expression for enjoying the moment or making the most out of what one is going through (Simpson 1987; cf. Qoh 2:24). This is one recommendation, among many, that is found consistently in the book of Qoheleth. Qoheleth recommends that in the face of toil and suffering, one should enjoy oneself for this
is a gift from God (Qoh 2:24; 3:12-13; 5:17-19; 8:15).

9.Good examples of the complaints include the books of Job and Lamentations and the prime example of 'the enjoy the moment' attitude would be the book of Qoheleth. 
about by childbirth as in the case of Genesis 3:16 or manual labour as in the cases of Adam and the Israelite slaves in Egypt (cf. Gn 3:17; Ex 3:7). It also includes pain brought about by sickness (cf. Job) and the effects of war and hunger. Mental or emotional pain is witnessed in cases of loss of loved ones as in the cases of Jacob (Gn 37:33-35), David (2 Sam 12:15-19; 18:33) and Job (1:20-22), and in the loss of land and independence, that is, the exile (cf. Ps 137 and the book of Lamentations).

Furthermore, even though there is no systematic treatment of suffering in the Old Testament, suffering is viewed from various dimensions. There is the issue of the origin or source of suffering. This issue is viewed from two perspectives: (1) that suffering is inherent in the nature of creation and (2) that suffering is a result of the transgression of God's law or the moral order established by God, that is, $\sin$.

In line with the first perspective, which is hinted at but is not as dominant as the second perspective, human suffering is considered to be part and parcel of being human (Gn 2-3; Qoh 1:12-18; Job 7:1-3). Indeed, for Qoheleth, this may be traced back to creation itself. It is said:

What is crooked cannot be made straight,

And what is lacking cannot be supplied. (Qoh 1:15)

Consider the work of God. Who can make straight

What he has made crooked? (Qoh 7:13)

This can be understood as conveying the message that all things have been ordained, and that defects in our nature as humans cannot be rectified by human knowledge or wisdom (cf. 8:17; Towner 1997:295). In other words, it all went wrong at the very beginning (cf. 3:9-13). At the beginning, God found his work of creation good (Gn 1) but not necessarily perfect (cf. Rm 8:18-21). God alone is perfect. The story of Adam and Eve at one and the same time attempts to account for this, as well as attempts to exonerate God. While God created everything out of his good will and generosity, and found it very good (cf. Gn 1:31), suffering which is the lot of human beings was not willed by God but is a consequence of the disobedience of the first human beings, according to Genesis 3 (cf. Wis 2:23-24). The effects of this disobedience were built into the very nature of being human (cf. Gn 3:16-17). According to the Old Testament account, these effects also disrupted the peaceful co-existence and relationships among the various members of creation. While human beings and animals were given fruits and vegetation for food in Genesis 1:29-31, they are permitted to kill and eat animal flesh after the flood of Noah (Gn 9:1-7). However, the prophets envision a time of renewal, a time of a new beginning when peaceful co-existence and cordial relationships among the various members of creation will be re-established (cf. Is 11:6-9). There will be no war (cf. Is 2:2-4; Mic 4:1-4). Everyone, from the least to the greatest will know God (Jr 31:31-34). In the meantime, however, suffering is to be taken as part of nature. As part of nature, human beings simply have to accept it and find ways to cope with it (Qoh 7:13-15). For Qoheleth, one has to learn to enjoy and appreciate every moment, for this is the life given by God and the lot of humanity (Qoh 5:17-19).

The second dimension, that human suffering is caused by $\sin$, is dominant in the Old Testament. Suffering is interpreted and understood in terms of retributive justice. ${ }^{10}$ In terms of this, actions have consequences. Good actions or good behaviour lead to reward, witnessed in prosperity, peace and a good life, while bad actions or bad behaviour lead to punishment, witnessed in suffering in all its dimensions. ${ }^{11}$ Retribution is either built-in within the moral order (Prov 10-11; cf. Adams 2008:1-5; Koch 1983; Schellenberg 2015:124) or it is seen in terms of the direct intervention of God. The latter is emphasised in the book of Deuteronomy, the Deuteronomistic History (cf. Dt 30:15-20, Jdg 2:6-23), in much of the Prophetic literature, in the book of Job and the Wisdom of Solomon. God is just and has the power and will to execute justice (cf. Gn 18:12-25; Ezk 18:1-32; 33:10-20; Wis $12: 12-18) .{ }^{12}$

Retributive justice has a corporate or collective as well as a personal or individual aspect. One may say that before the prophet Ezekiel, actions performed were understood to have consequences that affected the person and his family and the community at large (cf. Ex 20:5; 34:6-7; Nm 16:16-35). Noah's uprightness saved his family (Gn 6:5-9:29). Abraham's election by or covenant with God was extended to all his descendants (Gn 12:1-3; 15:1-21; 17:1-14). This communal or collective understanding was the basis of Abraham's intercession on behalf of Sodom and Gomorrah (Gn 18:16-33). In this understanding, the innocent were not necessarily spared. The defeat in war, famine, pestilence, roaming wild beasts and sickness that are understood as punishment do not make a distinction between the guilty and the innocent (Dt 28:15-69; Lv 26).

With Ezekiel and the experience of the Babylonian exile, the personal dimension of retributive justice receives more emphasis. Only the guilty suffer the consequences of their actions (Ezk 3:17-21; 14:12-23; 18:1-32; 33:1-20). God is just and he treats individuals justly, according to their behaviour, that is. Suffering therefore is understood to be a result of only punishment for sins. Not even the prayer of the righteous can save the guilty (Ezk 14:14, 20) as was the case with Abraham and Sodom and Gomorrah (Gn 18:16-33).

\footnotetext{
10.The dominance of this dimension is most apparent in texts written up to the time of the exile (Simundson 1992:220). In texts written during and after the exile, this of the exile (Simundson 1992:220). In texts written during and after the exile, this dimension receives persistent challenges from various quarters such that one could not take its dominance for granted. Three questions could have been centra to the challenge. Was Israel's God indeed omnipotent and just? Were the Israelites not more righteous than their Babylonian masters? Was the length and severity of the suffering endured leading up to and during the exile proportional? This experience and this questioning generated other alternatives which, however, did not completely reject the issue of retributive justice. Maybe, it would be more plausible to call them refinements of the teaching of just retribution. For one thing the 'alternatives' actually proceed from the presupposition of retribution. Furthermore, one still finds this teaching in the writings of Philo and in the New Testament A John 9:1-3.

11.Bergant (1984:10-11) traces the theory of retribution to wisdom thinking, practical wisdom that is.

12.The book of the Wisdom of Solomon goes further to insist that God's almighty power is made manifest in his saving justice and mercy (Wis 11:21-26; 12:16).
} 
The emphasis on the personal or individual aspect of retributive justice had the effect of accentuating and bringing into the open the problem of the suffering of the innocent, or the problem of 'undeserved' suffering, on the one hand, and the problem of the prosperity of the wicked, on the other hand (cf. Jr 12:1-5; Job 5; Ps 37; Ps 73). Before this, the teaching of just retribution was understood in the corporate sense. The consequence of sin, that is, suffering in all its manifestations swept both the guilty and innocent members of the community. With the exception of Deuteronomy 7:10; 24:16, there was no consistent and systemic discussion of the connection between an individual's behaviour and that individual's fate or fortune. ${ }^{13}$ Ezekiel's explicit connection between the two, echoed in Jeremiah 31:29-30, that guilty persons directly suffer the consequences of their sins (Ezk 14:12-23;18:1-32) exposed the limitation of not only Ezekiel's proposal but also the teaching of just retribution on which the proposal of Ezekiel was based. ${ }^{14}$

In the second part of the book of Isaiah, that is, Isaiah 40-55, often referred to as Second or Deutero-Isaiah, one witnesses another dimension to the Old Testament's interpretation and understanding of, as well as the Old Testament's grappling with the issue of suffering. What one reads in Isaiah 40-55 is not the rejection of the teaching of retribution but an invitation to go beyond this teaching. While suffering brought about by the exile is seen as a result of Israel's $\sin$ (Is 40:1-2; 43:22-28; 50:1), it is also emphatically interpreted as part of God's work in the world, part of his plan from of old (cf. Is 43:9-10). Furthermore, suffering of the servants of God, be it Israel as a whole, or some members of the community, ${ }^{15}$ could be interpreted and understood, not only in terms of retribution or as part of God's plan in the world but also as beneficial to the community and the world at large (Is 49:4-6).

Suffering of the innocent or undeserved suffering, from the point of view of the teaching of just retribution, is interpreted and understood as suffering in place and on behalf of others, what has been called vicarious suffering, in Isaiah 52:13-53:12. While this understanding emanates from the teaching of just retribution, it stretches this teaching to such an extent as to go against it. An innocent person suffers and yet the suffering is meant to fulfil the requirements of just retribution. Only that

13. Within the context of explaining the election of Israel, and exhorting her to keep God's covenant, in Deuteronomy 7:10, Moses goes on to warn them that God is faithful to those who love him and keep his commandments but punishes in their faithful to those who love him and keep his commandments but punishes in thei

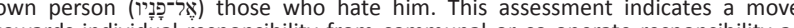
towards individual responsibility from communal or co-operate responsibility as expressed in Exodus 34:7, Deuteronomy 5:9 and Joshua 7:24 but legislated against in Deuteronomy $24: 16$ and 2 Kings 14:6. In Ezekiel 14 and 18, this move is made explicit. Both parents and their children suffer for their own sins.

14.Ezekiel's insistence on individual responsibility contributed to the Old Testament's understanding of the source of suffering, especially within the context of the exile, and the despair that accompanied it. For Ezekiel, Jerusalem was destroyed because of the sins of her then inhabitants, as he saw in the visions in chapter $8-10$, and not because of the sins of their forefathers. However, the focus on individual responsibility emphasised in Ezekiel made it easier to ascertain the relation or connection between the deeds of the individual and the fortune or fate of that individual. The result was a sustained debate and misgiving on the relevance and applicability of the teaching of just retribution in every individual relevance and applicability of the teacheng of just retribution in every individual instance. The books of Job and Qoheleth are prime examples of this challenge. Isaiah 52:13-53:12.

15.The identity of the servant is some passages in Isaiah $40-55$ is clear, but in some passages, it is ambiguous referring either to Israel as a nation or some individuals within and even without the nation of Israel. in this case, the suffering is for and on behalf of others. Furthermore, it combines both the individual and collective dimensions to the issue of just retribution. There is an individual suffering (this would, of course, depend on one's understanding of the identity of the servant - either as an individual or a group). The cause of the suffering and its effects are understood collectively (Is 53:4-7; cf. Gn 18:16-33; Jr 5:1; but also see Ezk 14:13-23).

The themes of just retribution and innocent suffering are topical in what has been called the wisdom literature and tradition (cf. Clifford 1997:13; Crenshaw 2010:19; Penchansky 2012:3). While wisdom texts and tradition are found in various parts of the Old Testament, the category wisdom literature is used to refer to the books of Proverbs, Job and Qoheleth, for the shorter canon, and Ben Sira and Wisdom of Solomon for the longer canon. ${ }^{16}$ In this literature, the teaching of just retribution is upheld (Pr 13:6; 26:27; Sir 16:1-21 and Wis 3:1-12), critiqued in the light of experience and faith (cf. Job), doubted and in some sense even abandoned in the light of the experience to the contrary, and in the light of the certainty and undiscriminatory nature of death (Qoh 8:14; 9:2-3). This has led some (cf. Bergant 1984) to propose that the teaching of just retribution emanated from wisdom thinking.

Within the framework of just retribution, the suffering of the innocent is grappled with and 'explained' or better still 'made sense of' in various ways in wisdom literature and tradition. These include the beliefs that none is just before God; suffering is disciplinary (Proverbs and Job); ultimate justice is meted out at death (Ben Sira) or in the afterlife (Wisdom of Solomon); or it is simply presented as a mystery (Job and Qoheleth). These aspects and more are to be found in Isaiah 52:13-53:12, a passage that grapples with the suffering of the innocent servant in terms of suffering for others. The nature of the suffering of the servant has been described as vicarious suffering.

\section{Vicarious suffering}

In the English language, vicarious suffering has been used to describe and categorise the nature of suffering that we witness in Isaiah 52:13-53:12. While this use is common among many commentators, it has been critiqued from various angles. The bone of contention seems to rest on the different understanding or rather the different emphases on the meaning and use of the word vicarious as well as on the argument that the term is foreign to the Old Testament (cf. Hooker 2010). The positive effect of this critique has been the recommendation that the phrase should be clarified when it is used to describe the nature of suffering in Isaiah 52:13-53:12 (cf. Hägglund 2008:12). In this section, the meaning and use of the term vicarious, the presence or

16.Wisdom literature is a category of books in the old Testament which have some common characteristics and some differences, of course. The common characteristics together with scholarly consensus have led to inclusion of Proverbs, Job, Qoheleth, Sira, Wisdom of Solomon and some Psalms under this category. This scholarly 'consensus' has received sporadic critique from the very beginning of the scholarly 'consensus' has received sporadic critique from the very beginning of the
use of the category Wisdom literature up to date. For a fairly recent discussion on this topic, see the articles in Sneed (2015) 
absence of this meaning and use in the Old Testament, especially with respect to innocent suffering shall be looked at.

\section{The meaning and use of 'vicarious'}

Etymologically, the word is derived from the Latin vicarius, which had the basic meaning of taking the place of a person or a thing, that is, substituting a person or a thing. ${ }^{17}$ In Latin, the word was used both as an adjective and a substantive. As an adjective, it described the taking of the place of a person or thing. As a substantive, it referred to someone who takes another's place, that is, a substitute or deputy. Interestingly, a slave who was owned by a slave, that is, another slave's peculium ${ }^{18}$ was sometimes called a vicarious.

The meaning and use of this word has expanded since it entered the English language in the 17th century. In the early 17 th century, it had the basic meaning of substitution. To this, basic meaning was gradually added the nuances of 'on behalf of others', experienced second hand, for example, through empathy, ${ }^{19}$ and experienced in another part of the body which is not normally associated with that function. To date, the word is used in various discourses with this expanded meaning; taking the place of another or empathy or experienced in another organ.

In the English language, taking the place of another can further be qualified. It can either be inclusive or exclusive. In the inclusive sense, the one who takes the place of another does so without removing the other from that place. In the case of experience, inclusive 'place-taking' denotes partaking or sharing in the experience that the other is experiencing. ${ }^{20}$ Other words that have been used for this include 'shared' place-taking (cf. Whybray 1978:30), 'representative' placetaking (cf. Hooker 1998:98) and 'in place with us' (cf. Gathercode 2015:19). While this inclusive sense includes the notion of empathy, that is, feeling with and for another, it goes beyond it.

In the exclusive sense, taking the place of another means that a person does not have to experience what they would have experienced, because another person has experienced it for them. Substitution is a word that is often used to denote this nuance of 'place-taking'. In the light of the discussion above, one can conclude that the meaning and use of the word vicarious in the English language to date captures both nuances of inclusive and exclusive 'place-taking'.

When the word vicarious is used to describe suffering, in the phrase 'vicarious suffering', it connotes a concept, a notion,

17.A related word is vicis, a genetive form of a word whose nominative form is not found in extant Latin literature. Vicis has been translated with change, interchange, alternation and as an adverb 'in vicem' - in place of instead of (Cassell 1991).

18.Peculium, in Roman society, referred to property a slave could own independent of the master.

19.For a discussion on the origins and meaning of the word empathy, and the relation between vicarious and empathetic pain from the perspective of philosophy of science, see De Vignemont and Jacob (2012:295-296).

20.Acknowledgment and credit is given to Bailey $(1998: 223,228)$ for the term 'placetaking' which he uses to translate the German Stellvertretung. Stellvertretung is used in the German language, in the discussions on the nature of the suffering in Isaiah 52:13-53:12. an idea in the realm of suffering. The meaning of this idea is captured in the adjective vicarious. In the light of the expanded use of the adjective highlighted above, vicarious suffering may refer to a suffering that is experienced by a person in place of another, what has been called 'place-taking'. This 'place-taking' can either be inclusive or exclusive. Hence, vicarious suffering may refer to the suffering a person 'shares' with another or with others, in one form or another, and for one reason or another. Empathetic suffering is a good example of this meaning of vicarious suffering. Vicarious suffering may also refer to the suffering that a person endures with the effect that others do not have to suffer the same. In this study, therefore, vicarious suffering is a suffering that is experienced in place of another, what we have called 'place-taking'. This 'place-taking' can either be inclusive or exclusive, shared or substitutionary. Vicarious suffering is therefore suffering in place of others. ${ }^{21}$

\section{Vicarious suffering in the Old Testament}

There has been debate concerning the presence of the idea of vicarious suffering, that is, suffering in place of others, in the Old Testament. There are those who contend that the idea is not only missing in the Old Testament but that it is also foreign to Old Testament thought (cf. Hooker 1998; Orlinsky 1969; Whybray 1978). These scholars limit the meaning of vicarious suffering to the idea of substitutionary suffering or what has been called exclusive 'place-taking' as far as suffering is concerned. There are also those who contend that the idea is present in the Old Testament, but its fullest expression is confined to one particular passage, that is, Isaiah 52:13-53:12 (cf. Barry 2010; Ejeh 2012; Spieckermann 2004). ${ }^{22}$ Even though its fullest expression is confined to Isaiah 52:13-53:12, it has been argued that its roots and background can be detected in various parts of the Old Testament (cf. Reventlow 1998:34-37; Spieckermann 2004; Zimmerli 1969).

The idea of taking the place of another, but not necessarily suffering in place of another, is scattered throughout the Old Testament. It is important for us to browse through the Old Testament and see the words, contexts and concepts where this idea is expressed. A number of words and expressions are used to convey the idea of taking the place of another. These words and expressions are used in various contexts and situations.

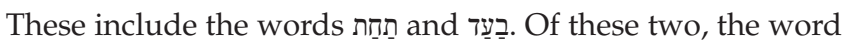
תַחָ is more frequently used. The word מַחת appears at least 506 times in the Old Testament (cf. Even-Shoshan 1997:1227-1229). It is used as a substantive or preposition. As the former, it is used to refer to something that is underneath, the under part (cf. Ex 24:4). As the latter it

21.This broad and expanded meaning is being proposed here because these are the nuances carried by the word in the English language.

22.The concept of vicarious suffering is not explored further beyond this text, a phenomenon that remains perplexing. However, the same concept seems to be phenomenon that remains perplexing. However, the same concept seems to be
expressed in the second book of Maccabees, where the righteous who suffer are said to suffer for the payment of the sins of the nation (cf. 2 Macc 6-7; cf. 4 Macc.; cf. Neusner \& Green 1996:603-604). 
indicates position - underneath (Gn 18:4) or taking the place of another (Nm 3:12; cf. Koehler \& Baumgartner 1998:1026). It occurs 187 times with the latter meaning and use.

The word תח is used in various contexts and situations with the meaning of taking the place of another or something (cf. Brown, Driver \& Briggs 2000:1066). In the story of the near 'sacrifice' of Isaac, it is used to describe the exchange that took place with the ram (Gn 22:13). It is used in the legal context to express just or equitable judgment, in the famous '... life for life, eye for an eye, tooth for a tooth, hand for hand, foot for foot ...' (Ex 21:23-24). ${ }^{23}$ It is used to talk about succession: 'royal' succession (1 Ki 1:30, 3:7; 1 Chr 29:23; 2 Chr 26:1), 'military' succession (2 Sam 17:25) as well as 'priestly' succession (1 Ki 2:35, Jr 29:26). Notably, it is used to talk about human life in exchange of another human life (1 Ki 20:39, 42, 2 Ki 10:24, Is 43:3-4). It is also used in God's declaration or 'setting apart' (לקח) of the Levites. They are set apart to take the place of all the firstborns of Israel (Nm 3:12, $41,45,8: 16,18)$. There is, however, no evidence of the use of the word in the context of a human being suffering in place of another. $^{24}$

Besides the word תחת and other related words, there are a number of practices that we find in the Old Testament where the idea of taking the place of another is expressed or at least implied. In the rituals of sin and guilt offerings, and the use of blood in many of the animal sacrifices, the idea of the sacrificial animal and its blood taking the place of the offeror is implied. In the Levitical system, this is expressed in a number of ways (Lv 4:1-6:7, 24-30; 7:1-10; Nm 15:22-26). One of the ways is in the prescription concerning the sacrificial victim. With regard to the sin offering (the חָּ the sacrificial victim is determined by the 'office' or role of the offeror. For the priest, a bull is prescribed. While for a prince, a ram is prescribed. For the other members of the community, a number of options are prescribed depending on the economic capability of the individual. The options include a goat or sheep, doves or pigeons. ${ }^{25}$ This differentiation indicates that the sacrificial victim is understood as taking the place of the offeror. In the case of the blood ritual, the blood is said to take the place of the life of the offeror $(\operatorname{Lv} 17: 11){ }^{26}$

Another important practice where the idea of taking the place of another is expressed is the 'practice of redemption' (פד). There is redemption with regard to the consecration of firstborn men to God. It was stipulated that every firstborn male, of humans and beasts alike, was to be dedicated to or

23.This is a law of recompense (lextalionis) rather than revenge. It guarded agains minimal or excessive compensatory judgements at court.

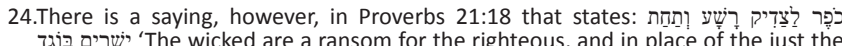

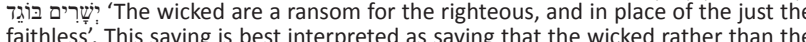
just suffer the evils of this world (cf. McCreesh 1993:459).

25.It is to be noted, however, that in Numbers 15:22-26, a bull is prescribed for the whole community.

26.The 'place-taking' in the Levitical sacrificial system has, of course, been interpreted in various ways, in terms of identification or representation or substitution (cf. Gathercode 2015). In this study, this place-taking expresses the idea of vicariousness as it has been defined above. set apart for the Lord (Ex 13:1-2, 11-16; 22:29b-30 [28b-29]; 34:19-20, Dt 15:19-23; cf. Childs 1976:194-195; Durham 1976:174-180). They were to be sacrificed to the Lord (Ex 13:15b). However, the firstborn male of donkeys was to be either redeemed by a lamb or to have its neck broken (Ex 13:13a). Similarly, the firstborn men of humans were to be redeemed (Ex 13:13b). The redemption, in the case of firstborn male donkeys by the lamb, means that the lamb takes the place of the donkey. ${ }^{27}$ This is also what is meant by redemption in the case of firstborn sons of human beings, even though the text is silent on the 'animal' that takes the place of, that is, redeems firstborn sons of human beings. ${ }^{28}$

Redemption has also been seen as one of the nuances in the use of the root כפר [atonement]. It has been argued that this word has two basic nuances: atonement through ritual purification (cf. Lv 15:31, 16:19; Nm 19:13, 20) and atonement through redemption (Ex 21:30; 30:12; Nm 35:3134; cf. Milgrom 1991:1082). In its use in the redemptive sense, there is the notion of 'place-taking' - vicariousness. There is redemption concerning people who find themselves in enslaving and life-threatening situations. In the covenant code, for example, there is a legislation that says that an owner of a known vicious bull that gores a person to death is to be put to death together with the bull. However, the legislation also gives the possibility of redemption on the part of the owner. They may pay something in place of their life (Ex 21:30). In Isaiah 43:3b, כפר is also used together with תחת to express the notion of taking the place of another. ${ }^{29}$

The above discussion has shown that the notion of 'placetaking', that is, vicariousness, is present in the Old Testament in various contexts. It has also been noted that a number of words are used to express this idea. That being the case, the question that comes to mind is whether in all these instances and uses, there is the notion of suffering for another (defined in this study as vicarious suffering). Precisely, are there instances where human beings suffer in place of other human beings? $?^{30}$

There are a number of instances where humans take the place of another. In the law of recompense, a life taken (murdered) was to be compensated (replaced) by the taking of the life of the offender (Ex 21:13-14).

The Levites take the place of the whole community in the

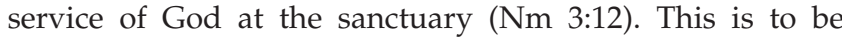
understood as service. The issue of suffering associated with

27.For the use of פith the meaning of taking the place of someone or something or replacement, in the texts highlighted above, see Cazelles (2001:483-490).

28.In the book of Numbers, the Levites are set apart to take the place of the first born of the Israelites (cf. Nm 3:12, 41, 45, 8:16, 18).

29.In this oracle of salvation, God promises to give Egypt as a ransom (כפר) and Seba 'in place of' (תחת) of Israel.

30.It has already been noted that in the sacrificial system, especially with respect to sin and guilt offering, including the sacrificial rites of the Day of Atonement (Lv 16), the sacrificial victim takes the place of the offeror. It suffers death in place of the offeror. For a contrary view, that of identification rather than substitution, see the Tubingen school clearly represented in the writings of Gese (1981) and Bernd Janowski (2004). For further discussions on the contribution of this school, also see Bailey (1998:236-250) and Gathercode (2015:39-45). 
this service, if any, is not mentioned. In Exodus 32:31-35, Moses offers to suffer the consequences of the sin of the apostasy of Israel. His offer is categorically denied by God. In response God says, 'Whoever has sinned against me I will blot out of my book' (Ex 32:33b).

In the Deuteronomic history, there are two instances (1 Ki 20:35-43; 2 Ki 10:24) where a person(s) is mandated to guard a captive or captives, a prisoner of war in the hypothetical case of 1 Kings 20:39 and of the ministers of Baal in the case of 2 Kings 10:24. They are to guard these with their very lives. In the case of an escape, they were to pay with their lives. This threat is not carried out in the case of 2 Kings 10:24, because no priest of Baal escaped. In 1 Kings 20:35-43, it is used to predict the death of Ahab. ${ }^{31}$ His death is seen as a consequence of his disobedience or failure to put Ben-Hadad, the king of Aram, to death. This goes to show that in the minds of those who told the story of the history of Israel, a human life could be exchanged for another in the form of punishment by death.

In Isaiah 52:13-53:12, there is a person who suffers sickness, pain and probably even death because of the sins of others (Is 53:4-6, 8-9, 12ag). This person has been traditionally given the title suffering servant. While the suffering of the servant is not doubted nor questioned, the nature of this suffering has generated much debate. Is the suffering of the servant a suffering 'in place of' others? Is it vicarious suffering?

Up to the middle of the 20th century CE, in the Christian tradition, at least, the suffering of the servant in Isaiah 52:13-53:12 was interpreted in terms of vicarious suffering by the majority of Christian commentators (cf. Westermann 1969:268). By the middle of the 20th century CE, however, a number of commentators began questioning the idea of vicariousness within the context of the Old Testament (Williams 2003:53-54). Two scholars who are often referred to, with respect to their challenge to the continual use of the concept of vicarious suffering for Isaiah 52:13-53:12, and the Old Testament in general, are Orlinsky (1969) and Norman Whybray (1978)

Arguing from his understanding of the nature of the Old Testament covenant and his understanding of the meaning of the word vicarious, Orlinsky (1969) concluded that the suffering of the servant in Isaiah 52:13-53:12 is not vicarious. For him, theological and scholarly guilds in postbiblical times and not the author of Isaiah 52:13-53:12 have made the discovery of vicariousness in this passage (Orlinsky 1969:246 and note 28,265$)$. The word vicarious, for him, conveys the idea of substitution. To suffer vicariously means that a person suffers for another in such a way that the other need not

31. The context of the text in 1 Kings 20:35-43 is the victory of Ahab over Ben-Hadad and the Syrians (1 Ki 20:1-34). Ben-Hadad surrenders to Ahab and pleads for clemency, and Ahab spares his life. One of the sons of the prophets, moved by the spirit of the Lord, disguised himself, presumably of one of spirt of the Lord, disguised himseldiers, and waited for Ahab. As Ahab was passing by the prophet told him that he, the prophet, was asked to guard a priso prisoner, hower, escaped. To this, Ahab said the sentence stands. At these words, the prophet removed the bandage he had used to disguise himself and accuses Ahab for sparing the life of Ben-Hadad. Ahab and his people were to pay for this with their own lives. to suffer. It means that one suffers instead of another who deserved to suffer. Furthermore, the nature of the covenant in the Old Testament does not allow an innocent human being to suffer in place of the guilty. It is the guilty who suffer the consequences of their sin (cf. Ex 32:31-35; Orlinsky 1969:246-247).

The concerns that Orlinsky raised are legitimate, if and only if we confine the meaning of vicarious to the nuance of substitution. As it has been proposed above, the use of this word has broadened in the English language. Substitution remains one of its meanings but not the only one. Vicariousness also means experiencing together with others, what is known as empathy. It means taking the place of another in the broadest sense of the word. With regard to the issue of the covenant, indeed under the covenantal stipulation, it is the guilty that suffer the consequences of their sin. But in the light of the communal or corporate dimension of the covenant, the consequences of the sins of the fathers were visited upon their children to the third and fourth generations (Ex 34:6-8). Experience also proved otherwise, such that the suffering of the innocent person became a perennial problem, especially among the sages. Vicarious suffering should be seen not only in terms of a restricted individual understanding of the covenant but also in its communal understanding and in the way the covenant was experienced and lived out.

Vicarious suffering, for Norman Whybray, means suffering in place of others, with the result that the ones who deserve to suffer no longer suffer (Whybray 1978:25). It is substitutionary suffering. For Whybray, this creates exegetical and theological problems. He demonstrates that by doing an exegesis of the words and phrases that have been traditionally used to support a vicarious meaning of the passage. ${ }^{32} \mathrm{He}$ concludes that none of these words and expressions is used in a vicarious sense, that is, substitutionary sense in the Old Testament (Whybray 1978:75; cf. Williams 2003:56-71). Furthermore, theologically, for him, it would mean that those who deserved to be punished were not punished, and that God accepted the suffering of the servant in place of others. This he finds unacceptable and contrary to Old Testament covenantal theology (Whybray 1978:63). Hence, for him, there are no words or phrases in Isaiah 52:13-53:12 that carry a substitutionary meaning. He says that what we have in this text is 'shared and not vicarious suffering' (Whybray 1978:30, 59).

Whybray concedes, however, that the servant suffers more intensely than the 'we' and was more innocent compared to them (Whybray 1978:30). Indeed, from the point of view of the 'we', they, the 'we', did not consider themselves as sharing in this intense suffering but considered themselves or their sins to be, on the one hand, the cause of this intense suffering, and, on the otherhand, to have been spared of it because of the servant (Is 53:4-6). Hence, their confession 
stated thus, 'our sufferings he carried, our wounds he carried' (Is 53:4a) and 'the punishment for our peace was upon him' (Is 53:5ba), can best be interpreted in terms of vicariousness in its broad meaning of place-taking. Furthermore, the phrase 'yet we considered him stricken, struck by God and afflicted' (Is 53:4b) would mean that the 'we' did not consider themselves as sharing in the suffering of the servant. Notwithstanding, their confession shows their empathy to the suffering of the servant. They were empathetic to whatever the servant went through on their behalf. Their empathy comes to the fore after the actual suffering of the servant, as they look back to what had happened and confessed their contribution to what the servant had to endure.

Having said this, the proposal of Chisholm (1991:331) is worth noting. He proposes that the language of Isaiah 52:13-53:12 is open to a vicarious interpretation, but it does not demand such an interpretation. In other words, the language is at best ambiguous (cf. Hägglund 2008:12). The language of carrying the wounds, sickness and iniquities of the 'we' (Is 53:4a, 11b, 12ba); of being wounded and crushed for their transgressions, guilt and well-being (Is 53:5, 8bb); of the Lord laying the guilt or punishment of the 'we' on him (Is 53:6b); and the language of making his life an wָ (Is 53:10ab), is indeed open to a 'place-taking', vicarious interpretation in the sense that has been adopted above. The servant suffered in place of the 'we' in the broad sense of the word.

It is also important to note that this text gives a new insight, a new understanding of the suffering of the innocent in the Old Testament. ${ }^{33}$ Indeed, this is a new insight, such that investigating the use and meaning of the words and phrases used to convey this insight from other parts of Old Testament will, of course, yield a negative result, as shown by the conclusions of Whybray (1978).

\section{Summary and concluding remarks}

The aim of this article was to determine the meaning of vicarious suffering and the presence of this concept in the Old Testament. Firstly, the phenomenon of suffering in general, and its expressions in the Old Testament in particular, was addressed. It was observed that suffering is part and parcel of the human experience.

Etymologically, the English word is derived from the Latin sufferre which means to carry a burden. It was also noted that according to the contemporary 'standard account', suffering is personal and it involves a perception of harm and threat, and that while pain is often associated with suffering, it does not necessarily cause suffering. Ultimately, suffering is a result of the failure to understand and accept what one is going through. This led to the definition of suffering as 'personal emotional anguish arising from various sources perceived to be harmful and life threatening'.

33.Some of the phrases are used in a unique way in this passage, for example, the phrase [שא ח [to bear sin]. The phrase appears nine times in the Old Testament, but it is used with the sense of bearing the sins of others only in Isaiah 53:12ba (cf. Whybray 1978:31).
As far as the Old Testament is concerned, it was observed that there is no systematic treatment of the subject of suffering but that the issue is discussed at various stages and in various contexts of the Old Testament. Suffering is understood in terms of carrying a burden and in terms of pain (physical, emotional and spiritual pain). It was also noted that according to the Old Testament account, the origin or source of suffering is viewed from basically two perspectives: that suffering is inherent in creation and that it is a consequence of the transgression of God's law. It was also established that the latter perspective led to what has been called the teaching of just retribution. It was noted that emphasis on retributive justice compounded the problem of the suffering of the innocent. This problem of the suffering of the innocent is one of the hallmark themes of the wisdom literature and tradition as well as a theme in the oracles of the anonymous exilic prophet responsible for the oracles in Isaiah 40-55. In Isaiah 52:13-53:12, the suffering of the innocent servant is interpreted in terms of suffering because of others, in place of others and for the benefit of others. This has been called vicarious suffering.

Secondly, the meaning and use of the concept of vicarious suffering and its presence or absence in the Old Testament were also studied. It became clear that the meaning and use of the Latin vicarius has expanded since it entered the English language. It now encompasses the meaning of taking the place of another as well as empathy. In English, taking the place of another can be inclusive or exclusive 'place-taking'. Hence, vicarious suffering is a suffering that is experienced in place of another (inclusive or exclusive). As to the presence of this concept in the Old Testament, the debate that continues among scholars of the Old Testament and the Bible in general was highlighted. Some words and practices in the Old Testament that express what has been defined as vicarious suffering were examined. At the end, it was concluded that while the idea of taking the place of another (vicariousness) in various contexts and situations is quite common, suffering in place of a or other human being(s) - vicarious suffering finds its unique, full and dramatic expression in Isaiah 52:13-53:12.

The meaning of vicariousness in Isaiah 52:13-53:12 can be understood in the broad sense of taking the place of another. Its meaning is open to both exclusive and inclusive 'placetaking'. Thus, the nuances of 'substitution' or 'replacement' and that of empathy (experiencing with others) are not mutually exclusive in this text. On the one hand, the servant was not only empathetic to the demise of the people, hence the servant's willingness expressed in Isaiah 53:10ab; 12, but also suffered instead of them (substitution). On the other hand, in their 'post factum' [after the fact] confession, the 'we' showed empathy to the suffering of the servant but they did not share in it when the servant endured it. Therefore, as this is the contemporary meaning and use of vicarious, the concept of vicariousness remains a useful tool in the study of the Old Testament account of suffering, especially 
the suffering of the innocent. The concept expresses the suffering of the innocent in terms of suffering in place of others and for their benefit, in the broad sense as is found in Isaiah 52:13-53:12 and is the current understanding of the concept.

\section{Acknowledgement Competing interest}

The authors declare that they have competing interest exists.

\section{Author contributions}

I declare that I am the sole author of this research article.

\section{Funding}

This research received no specific grant from any funding agency in the public, commercial, or not-for-profit sectors.

\section{Data availability statement}

Data sharing is not applicable to this article as no new data were created or analysed in this study.

\section{Disclaimer}

The views and opinions expressed in this article are those of the authors and do not necessarily reflect the official policy or position of any affiliated agency of the authors.

\section{Ethical consideration}

This article followed all ethical standards for carrying out research without direct contact with human or animal subjects.

\section{References}

Adams, S.L., 2008, Wisdom in transition: Act and consequence in second temple instructions, Brill, Leiden.

Akhtar, S., 2014, Sources of suffering: fear, greed, deception, betrayal and revenge, Karnac Books, London.

Bailey, D.P., 1998, 'Concepts of Stellvertretung in the interpretation of Isaiah 53', in W.R. Farmer \& W.H. Bellinger (eds.), Jesus and the suffering servant: Isaiah 53 and Christian origins, pp. 223-250, Trinity Press, Harrisburg, PA.

Barry, J.D., 2010, The Resurrected servant in Isaiah, Paternoster Press, Colorado Springs, $\mathrm{CO}$

Becking, B., 2009, 'Does exile equal suffering? A fresh look at Psal 137', in B. Becking \& D. Human (eds.), Exile and suffering, pp. 183-202, Brill, Leiden.

Becking, B. \& Human, D. (eds.), 2009, Exile and suffering, Brill, Leiden.

Bergant, J., 1984, What are they saying about wisdom? Paulist Press, New York.

Bowker, J., 1990, Problems of suffering in religions of the world, 3rd edn., Cambridge University Press, Cambridge.

Brown, F., Driver, R. \& Briggs, C., 2000, Hebrew and English Lexicon, 5th edn., Hendrickson Publishers, Inc., Peabody, MA.

Cassell, E.J., 1991, The nature of suffering and the goals of medicine, Oxford University Press, Oxford.

Cazelles, H., 2001, 'הדפ', in J.G. Botterweck, H. Ringgren \& H.J. Fabry (eds.), Theological Dictionary of the Old Testament, pp. 483-490, vol. X1, William B. Eerdmans, Grand Dictionary
Rapids, MI.

Chapman, R.C. \& Gavrin, J., 1999, 'Suffering: The contribution of persistent pain', The Lancet 353(9171), 2233-2237.

Childs, B., 1976, The book of Exodus: A critical theological commentary, Westminster Press, Louisville.

Chisholm, R.B., 1991, 'A theology of Isaiah', in: R.B. Zuck (ed.), A biblical theology of the Old Testament, pp. 305-340, Moody, Chicago, IL.
Clifford, R.J., 1997, 'Introduction to wisdom literature', in L.K. et al. (eds.), New Interpreter's Bible, vol. 5, pp. 1-16, Abingdon Press, Nashville, TN.

Crenshaw, J.L., 2010, Old Testament Wisdom: An introduction, 3rd edn., Wm John Knox Press, Louisville.

De Vignemont, F. \& Jacob, P., 2012, 'What is it like to feel another's pain?', Philosophy of Science 79(2), 295-316.

Durham, J., 1976, Exodus, Word Books, Waco, TX.

Ejeh, T.U., 2012, The Servant of Yahweh in Isaiah 52:13-53:12: A historical critical and Afro-cultural hermeneutical analysis with the Igalas of Nigeria in view, 1st edn., LIT Verlag, Berlin.

Even-Shoshan, A. (ed.), 1997, A new concordance of the Old Testament: Using the Hebrew and Aramaic Text, 2nd edn., KiryatSefer Publishing House, Jerusalem.

Gathercode, S., 2015, Defending substitution: An essay on atonement in Paul, Baker Academic, Grand Rapids, MI.

Gese, H., 1981, 'Atonement', in K. Crim (ed.), Essays on biblical theology, pp. 93-116, Augsburg, MN.

Hägglund, F., 2008, Isaiah 53 in the light of Homecoming after exile, Mohr Siebeck, Tubingen.

Herdt, J.J., 2001, 'The rise of sympathy and the question of divine suffering', The Journal of Religious Ethics 29(3), 367-399.

Hooker, M., 2010, Jesus and the servant: The influence of the servant concept of Deutero-Isaiah in the New Testament, Wipf and Stock, Eugene, OR.

Hooker, M.D., 1998, 'Did the use of Isaiah 53 to interpret His mission begin with Jesus?', in W.R. Farmer \& W.H. Bellinger (eds.), Jesus and the suffering servant: Isaiah 53 and Christian origins, pp. 89-103, Trinity Press, Harrisburg.

Hudson, W., 2012, 'Historicizing suffering', in J. Malpas \& N. Lickiss (eds.), Perspectives on human suffering, pp. 171-182, Springer, London.

Humbert, P., 1918, 'The Old Testament and the problem of suffering', Biblical World 52(2), 115-135.

Janowski, B., 2004, 'He bore our sins: Isaiah 53 and the drama of taking another's place', in P. Stuhlmacher \& B. Janowski (eds.), The Suffering Servant: Isaiah 53 in Jewish and Christian sources, pp. 48-74, Eerdmans, Grand Rapids, MI.

Koch, K., 1983, 'Is there a doctrine of retribution in the Old Testament?', in J.L. Crenshaw (ed.), Theodicy in the Old Testament, pp. 57-87, Fortress Press, Philadelphia, PA.

Koehler, L. \& Baumgartner, W., 1998, A Bilingual dictionary of the Hebrew and Aramaic Old Testament, Brill, Leiden.

Laato, A. \& de Moor, J., 2003, Theodicy in the world of the Bible, Brill, Leiden.

Liderbach, D., 1992, Why do we suffer? New ways of understanding, Paulist Press, New York.

Magnante, A., 1997, Why suffering? The mystery of suffering in the Old Testament, Pauline Publications, Nairobi City.

Malpas, J. \& Norelle, L., 2012, Perspectives on human suffering, Springer, London.

McCreesh, T.P., 1993, 'Proverbs', in R.E. Brown, J. Fitzmyer \& R.E. Murphy (eds.), NJBC, pp. 453-465, Geoffrey Chapman, NJ.

Milgrom, J., 1991, Leviticus 1-16: A new translation with introduction and commentary, vol. 3, Doubleday, New York.

Morgan, C.W. \& Peterson, R.A., 2008, Suffering and the goodness of God, Crossway, Wheaton.

Neusner, J. \& Green, W.S., (eds.), 1996, Dictionary of Judaism in the biblical period: 450 B.C.E. to 600 C.E., Hendrickson Publishers, New York.

Orlinsky, H.M., 1969, 'The so-called "suffering servant" in Isaiah 53', in H.M. Orlinsky (ed.), Interpreting the Prophetic Tradition, pp. 225-274, Hebrew Union College Press, Cincinnati, $\mathrm{OH}$

Pearsall, J. \& Trumble, B. (eds), 2002, Oxford English reference dictionary, 2nd edn., Oxford University Press Oxford.

Penchansky, D., 2012, Understanding wisdom literature: Conflict and dissonance in the Hebrew text, Wm. B. Eerdmans, Grand Rapids, MI.

Reventlow, H.G., 1998, 'Basic Issues in the interpretation of Isaiah 53', in W.H. Bellinger \& W.R. Farmer (eds.), Jesus and the suffering servant: Isaiah 53 and Chrisitian origins, pp. 23-38, Trinity Press, Harrisburg, PA.

Schellenberg, A., 2015, 'Don't throw the baby out with the bathwater: On the distinctiveness of the sapiential understanding of the world', in M.R. Sneed, (ed.), Was there a wisdom tradition? New prospects in Israelite wisdom studies, pp. 115-143, Society of Biblical Literature Press, Atlanta.

Simundson, D.J., 1992, 'Suffering', in D.N. Freedman \& A.B. Beck, (eds.), Anchor Bible Dictionary, volume 6, pp. 219-225, Doubleday, New York.

Simpson, D., 1987, Cassell's Latin-English Dictionary, 5th edn., Continuum, London.

Sneed, M.R. (ed.), 2015, Was there a wisdom tradition?: New prospects in Israelite wisdom studies, Society of Biblical literature Press, Atlanta.

Sollereder, B., 2015, 'When humans are not unique: Perspectives on suffering and redemption', Expository Times 127(1), 17-22.

Spieckermann, H., 2004, 'The conception and prehistory of the idea of vicarious suffering in the Old Testament', in B. Janowski \& P. Stuhlmacher (eds.), The suffering servant: Isaiah 53 in Jewish and Christian Sources, pp. 1-15, Wm.B. Eerdmans, Grand Rapids, MI.

Towner, S.W., 1997, 'The book of Ecclesiastes', in L.E. Keck et al. (eds.), The New Interpreter's Bible, vol. 5, pp. 265-360, Abingdon Press, Nashville, TN. 
Villiers, D.G., 2009, 'Sin, suffering, sagacity: Genesis 2-3', Old Testament Studies 50, 4-17.

Westermann, C., 1969, Isaiah 40-66: A commentary, Westminster Press, Philadelphia, PA.

Whybray, R.N., 1978, Thanksgiving for a liberated prophet: An interpretation of Isaiah chapter 53, JSOT Press, Sheffield.
Williams, J.T., 2003, 'Jesus the servant - vicarius sufferer: A reappraisal', in: G.R. Wooden, T.R. Ashley \& R.S. Wilson, (eds.),"You will be my witness": A festschrift in honor of the reverend Dr. Allison A. Trites on the occasion of his retirement, pp. 53-80, Mercer University Press, Macon, GA.

Zimmerli, W., 1969, 'Zurvorgeschichte von Jes.liii', VetusTestamentum Supplements 17, 236-244, Brill, Leiden. 